Article

\title{
Derivation of the Spatial Distribution of Free Water Storage Capacity Based on Topographic Index
}

\author{
Bingxing Tong, Zhijia Li, Cheng Yao * $\mathbb{C}$, Jingfeng Wang and Yingchun Huang \\ College of Hydrology and Water Resources, Hohai University, Nanjing 210098, China; \\ 161301010079@hhu.edu.cn (B.T.); zhijia-li@vip.sina.com (Z.L.); jingfeng.wang@ce.gatech.edu (J.W.); \\ yingchunhuang@hhu.edu.cn (Y.H.) \\ * Correspondence: yaocheng@hhu.edu.cn; Tel.: +86-025-8378-7478
}

Received: 9 September 2018; Accepted: 6 October 2018; Published: 10 October 2018

\begin{abstract}
Free water storage capacity, an important characteristic of land surface related to runoff process, has a significant influence on runoff generation and separation. It is thus necessary to derive reasonable spatial distribution of free water storage capacity for rainfall-runoff simulation, especially in distributed modeling. In this paper, a topographic index based approach is proposed for the derivation of free water storage capacity spatial distribution. The topographic index, which can be obtained from digital elevation model (DEM), are used to establish a functional relationship with free water storage capacity in the proposed approach. In this case, the spatial variability of free water storage capacity can be directly estimated from the characteristics of watershed topography. This approach was tested at two medium sized watersheds, including Changhua and Chenhe, with the drainage areas of $905 \mathrm{~km}^{2}$ and $1395 \mathrm{~km}^{2}$, respectively. The results show that locations with larger values of free water storage capacity generally correspond to locations with higher topographic index values, such as riparian region. The estimated spatial distribution of free water storage capacity is also used in a distributed, grid-based Xinanjiang model to simulate 10 flood events for Chenhe Watershed and 17 flood events for Changhua Watershed. Our analysis indicates that the proposed approach based on topographic index can produce reasonable spatial variability of free water storage capacity and is more suitable for flood simulation.
\end{abstract}

Keywords: free water storage capacity; topographic index; floods simulation; Grid-Xinanjiang model; spatial distribution

\section{Introduction}

As hydrological models play increasingly important roles in operational flood forecasting, numerous lumped and physically-based hydrologic models have been developed over the last half-century, including the Standford model in the US, the Tank model in Japan, and the Xinanjiang model in China [1-7]. Although lumped models have simplistic and effective characteristics, they only partially capture the effect of a watershed's spatial variability on hydrological processes. Therefore, hydrologists are widely interested in distributed models in order to overcome the deficiencies of lumped models. Distributed models, such as the Grid-Xinanjiang model (GXM), the Systeme Hydrologique Europeen (SHE), Topography based hydrological model (TOPMODEL), and the hydrological enhanced version of the Weather Research and Forecasting model (WRF-Hydro), explicitly resolve spatial variability of topography, land-cover, and rainfall [8-14]. A majority of distributed hydrologic models are physical-based as they are defined in light of mass and momentum conservation equations. Estimating the spatial distributions of model parameters based on geographical characteristics of watersheds is particularly important for the applications of distributed hydrologic models [15-20]. For example, the parameters of MIKE SHE model are mainly dependent 
on soil properties including soil layer thickness, soil porosity, and hydraulic conductivity [21]. The key parameters of TOPMODEL are related to terrain topography [22].

The GXM, which integrates features from the conceptual rainfall-runoff model and the physically based flow routing model, has been proposed for flood simulation and operational forecasting [23-26]. The GXM uses identical square cells from the digital elevation model (DEM) as primary computational elements. These elements simulate five hydrologic processes including interception, direct channel precipitation, evapotranspiration, runoff generation, and slope and channel flow routing. One unique feature of the GXM is to parameterize runoff generation due to storage repletion. Runoff is separated into surface, interflow, and groundwater component according to the free water storage. Within each grid cell, runoff is further separated into surface runoff $\left(R_{s}\right)$, interflow $\left(R_{i}\right)$, and groundwater $\left(R_{g}\right)$ components, according to free water storage. For each runoff component, outflow of every grid cell is routed from cell to cell according to the upstream to downstream computation sequencing of grid cells. At the outlet of the watersheds, these runoff components add up to account for the total runoff. The GXM model explicitly parameterizes surface runoff, subsurface flow, and groundwater runoff based on hydraulic routing using the Muskingum method or the diffusion wave method [25]. Keeping the features of the widely used Xinanjiang (XAJ) model facilitates the implementation and operation of the GXM.

Two key parameters of the GXM, as well as the XAJ model, are the spatially variable tension water storage capacity $\left(W_{M}\right)$ and free water storage capacity $\left(S_{M}\right)$. For $W_{M}$, there are physically based methods for estimating its spatial distribution, such as Shi and Yao [25,27]. Yet the free water storage capacity remains empirical. The main goal of this paper, therefore, is to develop a physical based method to estimate the spatial distribution of free water storage capacity.

\section{Parameterization of $W_{M}$ and $S_{M}$ in the XAJ Model}

The XAJ model [28-32] assumes Horton runoff to be the dominant runoff generation mechanism, where runoff, not produced until soil moisture of the aeration zone reaches field capacity (water held by soil against gravity), is equal to rainfall excess without further loss. Since the 1970s, the XAJ model has been successfully applied to numerous humid and semi-humid regions in China. Horton's runoff has two components: surface and groundwater runoff. Kirkby argued that a third component, interflow, should be considered as infiltration rate varies through soil layer $[33,34]$. Upper soil often has higher permeability than lower soil leading to a relatively impermeable layer in-between. Infiltrating water from the upper soil will flow laterally, driven by topography-i.e., interflow, which is now included in the XAJ model.

In the XAJ model, a watershed is divided into sub-basins where outflow from each sub-basin is routed down river channels to the outlet of the main watershed. The XAJ model simulations of sub-basin outflow have four major parts: (1) the deficit of soil water storage due to evapotranspiration is distributed through the entire soil layer; (2) runoff production depends on rainfall and soil storage deficit; (3) runoff is partitioned into the surface, subsurface, and groundwater flow; (4) the local runoff is routed to the outlet of a sub-basin

The difference between field capacity and total soil water content is defined as tension water storage capacity, the maximum amount of water available in unsaturated zone [35-38]. In humid regions, soil moisture often reaches field capacity through the entire soil layer. When soil moisture is below field capacity, infiltration excessive runoff may be produced. Non-uniform spatial distribution of soil water shortage results in a variable distribution of runoff [39-44]. A tension water capacity curve is introduced (see Figure 1a) to describe the non-uniform distribution of tension water capacity throughout basin or sub-basin. In Figure $1 \mathrm{a}, I M$ is the proportion of impermeable area to total watershed area, $A U$ the initial tension soil water content, $P$ the cumulative precipitation over a certain period of time, $K$ the ratio of potential evapotranspiration to pan evaporation, $E M$ the measured pan evaporation, $W$ the areal mean tension water storage, $F R$ the $W$-dependent runoff contributing area factor, and $B$ the exponent of the tension water capacity distribution curve. $F$ is the total watershed 
area. $f$ represents the area of the watershed whose tension water capacity is less than or equal to $W_{M}$. The tension water capacity at a point, $W_{M}$, is expressed as,

$$
1-\frac{f}{F}=\left(1-\frac{W_{M}}{W_{M \max }}\right)^{B}(1-I M)
$$

where $W_{M \max }$ is the maximum $W_{M}$. After soil moisture in an unsaturated zone reaches the field capacity, rainfall entering the reservoir becomes free gravity water until the reservoir is full to produce subsurface runoff. If rain continues, groundwater runoff reaches its limit and the overflow of reservoir becomes surface runoff. The reservoir capacity is assumed to be equal to free water capacity, $S_{M}$ [45-48], which plays an important role in the partition of surface and subsurface runoff. Similar to that of tension water capacity, the distribution curve of $S_{M}$, illustrated in Figure 1b, where the free water capacity, $S_{M}$, varies from zero to a maximum $S_{M \max }$ :

$$
\left(1-\frac{f_{r}}{F R}\right)=\left(1-\frac{S_{M}}{S_{M \max }}\right)^{E X}
$$

where $S_{M \max }$ is the maximum $S_{M}, f_{r}$ is the portion of the basin area with free water storage capacity less than or equal to $S_{M}, E X$ the exponent of the free water capacity distribution curve, and FR the runoff contributing area.

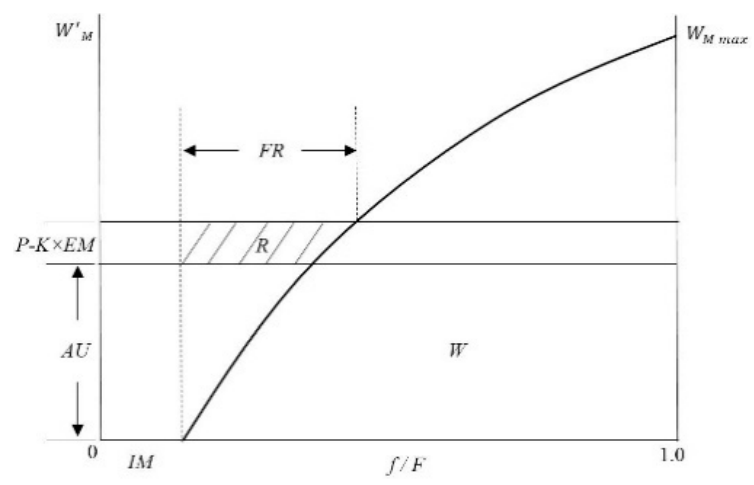

(a)

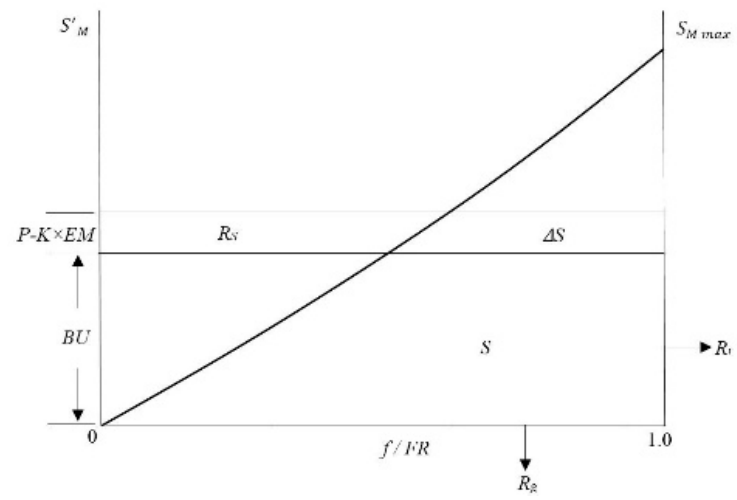

(b)

Figure 1. The distribution of tension water capacity and free water capacity in watershed: (a) tension water capacity (b) free water capacity.

\section{Spatial Distribution of $S_{M}$ in the GXM}

\subsection{Runoff Generation and Separation}

Surface runoff $R_{s}$, interflow $R_{i}$, and groundwater runoff $R_{g}$ are related to free water storage $S$ :

$$
\begin{gathered}
R_{i}=K_{i} S \\
R_{g}=K_{g} S
\end{gathered}
$$

when $R+S \leq S_{M}$ :

$$
R_{S}=0
$$

and when $R+S>S_{M}$ :

$$
R_{S}=R+S-S_{M}
$$

where $K_{i}$ is the outflow coefficient of free water storage to interflow, $K_{g}$ is the outflow coefficient of free water storage to groundwater flow. In the GXM, the sum of $K_{i}$ and $K_{g}$ can be fixed and taken as 0.7 according to experience and practical operation in forecasting. 


\subsection{Estimation of $S_{M}$ in the $G X M$}

In the GXM, the method of estimating $S_{M}$, in which the spatial distribution of $S_{M}$ in the GXM is obtained based on vegetation and soil properties, could be referred to as the "VS method",

$$
S_{M}=\left(\theta_{s}-\theta_{f c}\right) L_{h}
$$

where $\theta_{s}$ is saturated water content, $\theta_{f c}$ is field capacity, $\theta_{w p}$ is the wilting point, $L_{a}$ is unsaturated zone thickness, and $L_{h}$ is humus thickness. $L_{a}$ and $L_{h}$ are expressed as,

$$
\begin{gathered}
L_{a}=\varepsilon_{a} T i+\varepsilon_{b} \\
L_{h}=\vartheta_{k} L_{a} \\
\varepsilon_{a} T i_{\text {min }}+\varepsilon_{b}=L_{a \text { max }}=\frac{W_{M \text { max }}}{\theta_{f c, T i_{\text {min }}}-\theta_{w p, T i_{\text {min }}}} \\
\varepsilon_{a} T i_{\text {max }}+\varepsilon_{b}=L_{a \text { min }}=\frac{W_{M \text { min }}}{\theta_{f c, T i_{\text {max }}}-\theta_{w p, T i_{\text {max }}}}
\end{gathered}
$$

where $T i_{i}$ is the topographic index, $T i_{\min }$ and $T i_{\max }$ the minimum and maximum topographic index of the watershed, respectively, and $W_{M \min }$ and $W_{M \max }$ minimum and maximum $W_{M}$ of the watershed, respectively. $L_{a} \min$ and $L_{a} \max$ are the minimum and maximum $L_{a}$ of the watershed, respectively. The coefficients $\varepsilon_{a}$ and $\varepsilon_{b}$ are parameterized in terms of topographic index and $W_{M} . \vartheta_{k}$ is the conversion coefficient of humus thickness, depending on unsaturated zone thickness. In practice, the resolutions of vegetation cover and soil type data are often too low for modeling runoff over small watersheds; field observations of $\theta_{s}, \theta_{f_{c}}$, and $\theta_{w p}$ are limited if available at all. Estimation of $S_{M}$ using high resolution topography data is desirable.

\subsection{Estimation of $S_{M}$ from Topographic Index}

The idea of using watershed topography to estimate distributed model parameters has been proposed in previous research, such as TOPMODEL. In TOPMODEL, the terrain index is expressed in terms of terrain topography and hydrological parameters. One parameterization of $W_{M}$ is the Logarithmic Weibull Curve with Zero Displacement [27].

$$
\frac{W_{M}}{W_{M \max }}=\operatorname{EXP}\left\{-\left[\frac{\ln \left(T i-T i_{\min }+1\right)}{\alpha}\right]^{\beta}\right\}
$$

where $\alpha$ and $\beta$ are empirical coefficients. Combining Equations (1) and (12) leads to a relationship between $S_{M}$ and topographic index:

$$
1-\frac{S_{M}}{S_{M \max }}=\left\{1-E X P\left[-\left[\frac{\ln \left(T i-T i_{\min }+1\right)}{\alpha}\right]\right]^{\beta}\right\}^{b / E X}
$$

Equation (13), referred to as "terrain method", is the proposed method for estimating the spatial distribution of $S_{M}$, based on topographic characters of watersheds, and establishes a functional relationship between free water storage capacity and topographic index. The $S_{M \max }, B$ and EX can be roughly estimated according to the application experience of the Xinanjiang model within watersheds. The values of $\alpha$ and $\beta$ can be obtained referring to [27]. Ti and Timin can be calculated according to the geographical characteristics of the watershed.

The Equation (13) show that locations with larger values of free water storage capacity generally correspond to locations with higher topographic index values, such as riparian region. Through this correspondence, the $S_{M}$ can be estimated by $T i$ of the known spatial distribution law. For the 
estimation of $S_{M}$ spatial distribution, the following steps are taken: (1) calculate topographic index based on DEM; (2) construct Logarithmic Weibull Curve (Equation (12)) with the operate experience of Xinanjiang model and the statistical results of topographic index; (3) based on the Logarithmic Weibull Curve, an equation (Equation (13)) for describing the spatial distribution of $S_{M}$ is educed by combining Equations (12) and (1). In addition, Equation (13), referred to as "terrain method", has been implemented in Chenhe and Changhua watersheds to compare the VS method (Equation (7)). The comparison of the XAJ model and GXM with $S_{M}$, estimated using the terrain method, is discussed in Section 5.

\section{Case Studies}

\subsection{Study Areas and Data}

The proposed spatial distribution method was tested on two watersheds. The first was the Chenhe Watershed, located in in the mountainous region of the ShannXi Province. It features a $1395 \mathrm{~km}^{2}$ drainage area with nine rain gauges, and elevations ranging from $630 \mathrm{~m}$ above sea level at the watershed outlet, to $3747 \mathrm{~m}$ (see Figure 2a). The Chenhe Watershed is covered with warm temperate deciduous broad-leaved and conifer forest. The long-term average annual rainfall, pan evaporation, and runoff from 1998 to 2012 were $867 \mathrm{~mm}, 426 \mathrm{~mm}$, and $471 \mathrm{~mm}$, respectively. Due to the dominance of monsoon climate, more than $60 \%$ of annual rainfall occurs during June to September (flood season). The rainfall and discharge records of 10 flood events from the Chenhe Watershed during 2003 to 2012 were used to evaluate the GXM performance, with $S_{M}$ as a model parameter. The spatial distribution of rainfall was obtained from interpolating the rainfall data from the nine rain gauges (see Figure 2a) using the inverse distance squared procedure. Due to the lack of continuous evaporation data for the calibration period, E-601 pan evaporation data collected at adjacent watershed were used as a surrogate. Other hydro-meteorological data from the Hydrology and Water Resources Survey Bureau of Shannxi Province for the period of 2003-2009 were used for model calibration and validating the remaining data.

The Changhua Watershed is located in the northwest mountainous area of the Zhejiang Province. It features a $905 \mathrm{~km}^{2}$ drainage area with elevations ranging from $96 \mathrm{~m}$ above sea level at the watershed outlet, to $1748 \mathrm{~m}$ (see Figure 2b). With the influence of the summer monsoon, the annual rainfall is as high as $1638 \mathrm{~mm}$. The hourly rainfall and discharge data from 17 flood events (1998-2010) in the Changhua Watershed were obtained from the Hydrology and Water Resources Survey Bureau of the Zhejiang Province. Daily pan evaporation data from the Changhua station are also available.

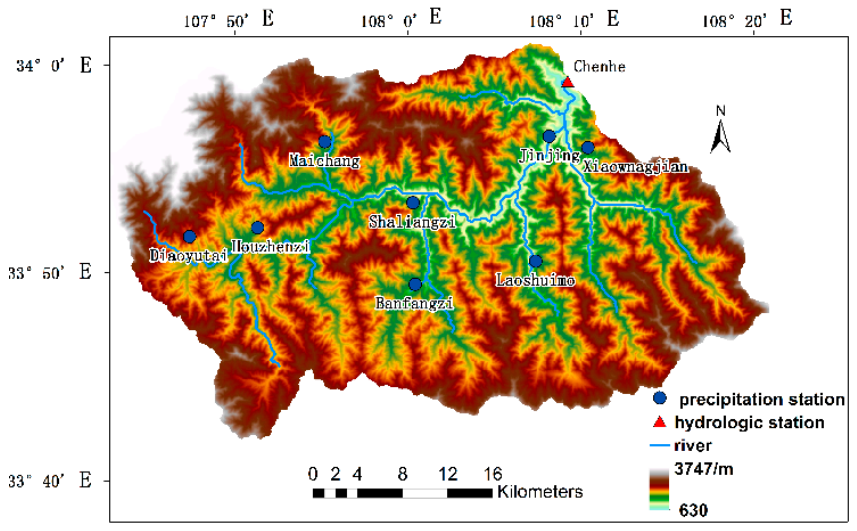

(a)

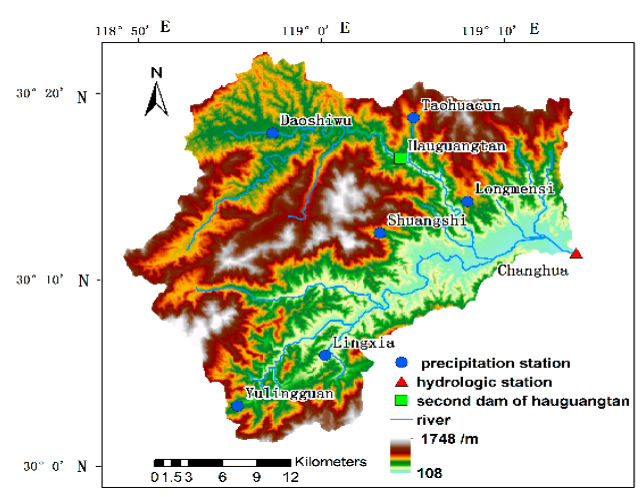

(b)

Figure 2. Digitial elevation model (DEM) and precipitation station: (a) Chenhe Watershed (b) Changhua Watershed. 
Two dams of the Huaguangtan Reservoir were built in the Changhua Watershed at $108^{\circ} \mathrm{E} 30^{\circ} \mathrm{N}$ in 2008. The first dam of $103 \mathrm{~m}$ height is the main water retaining structure for water storage and power generation. The second dam, $3 \mathrm{~km}$ downstream from the first, is used for water level control related to the operation of the first dam. The water collecting area above the second dam is $350.7 \mathrm{~km}^{2}$, which accounts for about $1 / 3$ of the watershed. Hydrological data of the Changhua Watershed are divided into two periods for model calculation: 1998-2008 and 2008-2010. The GXM takes the Huaguangtan Reservoir as a compute node in order to address its effect. In other words, using the Muskingum method, the outflow of the Huaguangtan Reservoir is regarded as the inflow of downstream channel and directly routed to the outlet of watershed. The runoff generation and concentration for the upper region of the reservoir were not taken into consideration for the application of GXM.

The digital elevation model (DEM) with a spatial resolution of $1 \mathrm{~km}\left(30^{\prime \prime}\right)$ was obtained from the US Geological Survey [24] and used to derive the topographic attributes of the watershed. Moreover, $1 \mathrm{~km}$ of vegetation data are available from the University of Maryland (UMD) Land Cover Classification. Lastly, $10 \mathrm{~km}$ of soil texture data are provided by the US Food and Agriculture Organization [24].

\subsection{Testing the GXM}

The GXM flood simulations used $S_{M}$ to estimate the terrain method (Table 1), where FloodNo is the number of flood events, RRE is the relative runoff error, RPE is the relative peak error, RTE the is difference in peak time, and NS is the Nash-Sutcliffe efficiency defined as:

$$
\begin{gathered}
R R E=\frac{R_{\text {sim }}}{R_{o b s}}-1 \\
R P E=\frac{Q_{\text {sim }}}{Q_{o b s}}-1 \\
R T E=T_{\text {sim }}-T_{o b s} \\
N S=1-\frac{\sum_{t=1}^{z}\left|Q_{s i m}^{t}-Q_{o b s}^{t}\right|^{2}}{\sum_{t=1}^{z}\left|Q_{\text {sim }}^{t}-\overline{Q_{o b s}}\right|^{2}}
\end{gathered}
$$

Table 1. Statistics of flood simulations.

\begin{tabular}{cccccccccc}
\hline Period & FloodNo & $\begin{array}{c}\mathbf{R}_{\text {obs }} \\
(\mathbf{m m})\end{array}$ & $\begin{array}{c}\mathbf{R}_{\text {sim }} \\
(\mathbf{m m})\end{array}$ & $\begin{array}{c}\mathbf{R R E} \\
\mathbf{( \% )}\end{array}$ & $\begin{array}{c}\mathbf{Q}_{\text {obs }} \\
\left.\mathbf{( m}^{3} / \mathbf{s}\right)\end{array}$ & $\begin{array}{c}\mathbf{Q}_{\text {sim }} \\
\left(\mathbf{m}^{3} / \mathbf{s}\right)\end{array}$ & $\begin{array}{c}\text { RPE } \\
(\mathbf{\%})\end{array}$ & RTE & NS \\
\hline \multirow{6}{*}{ Cal } & 2003090319 & 67.3 & 70.7 & 5.07 & 740 & 764 & 3.27 & -1 & 0.96 \\
& 2003091711 & 76.3 & 79.0 & 3.54 & 694 & 714 & 2.91 & -3 & 0.89 \\
& 2005092413 & 191.7 & 223.0 & 16.30 & 1191 & 1295 & 8.79 & -2 & 0.75 \\
& 2005092520 & 175.1 & 202.3 & 15.48 & 1740 & 1847 & 6.15 & 2 & 0.78 \\
& 2008071909 & 27.4 & 29.6 & 7.90 & 618 & 626 & 1.26 & -1 & 0.79 \\
& 2009071419 & 32.9 & 38.8 & 18.04 & 195 & 200 & 2.37 & 1 & 0.86 \\
\hline \multirow{6}{*}{ Ver } & 2010072116 & 68.9 & 79.1 & 14.76 & 527 & 624 & 18.35 & -1 & 0.75 \\
& 2011091008 & 57.4 & 59.2 & 2.98 & 865 & 805 & -6.93 & 2 & 0.93 \\
& 2011091520 & 110.1 & 105.0 & -4.56 & 1200 & 1131 & -5.79 & -2 & 0.96 \\
& 2012083013 & 84.5 & 78.9 & -6.64 & 1710 & 1718 & 0.47 & 0 & 0.91 \\
\hline
\end{tabular}

The first four digits of FloodNo represent the year, the fifth and sixth digits represent the month, the seventh and eighth digits represent the day, and the ninth and tenth digits represent the time of flood occurrence. $R_{o b s}$ is the observed runoff, $R_{\text {sim }}$ the simulated runoff, $Q_{o b s}$ the observed peak discharge, $Q_{\text {sim }}$ the simulated peak discharge, $T_{\text {sim }}$ the simulated time of peak flow, $T_{\text {obs }}$ the observed time of peak flow, $Q_{o b s}^{t}$ the observed discharge at time step $\mathrm{t}, Q_{\text {sim }}^{t}$ the simulated peak discharge at $\mathrm{t}$, $\overline{Q_{o b s}}$ the observed mean over the time period of analysis, and $\mathrm{z}$ the total number of times. NS equals to 1 if simulated hydrography agrees with the observed. 


\section{Results and Discussion}

Based on topographic index, the Logarithmic Weibull Curve (Equation (12)) was constructed to derive the equation (Equation (13)) describing the spatial distribution of $S_{M}$. Moreover, the application of Equation (13) — referred to as the "terrain method" — was less successful than the XAJ and the GXM in the Chenhe and Changhua watersheds. The spatial distribution of $S_{M}$ in the Chenhe and Changhua watersheds can be estimated from Ti-Timin, using the DEM data (Equation (13)). The estimated $S_{M}$ used in the flood simulations for the Chenhe and Changhua Watershed is shown in Figure 3.

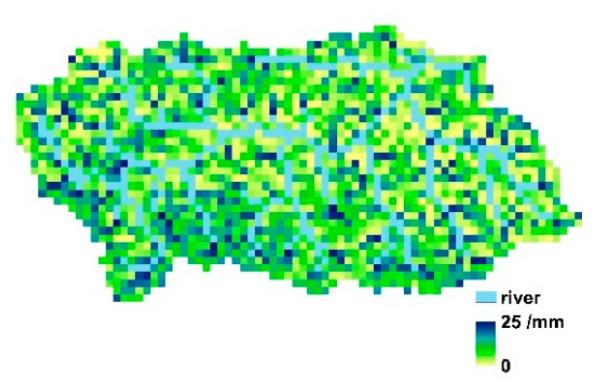

(a)

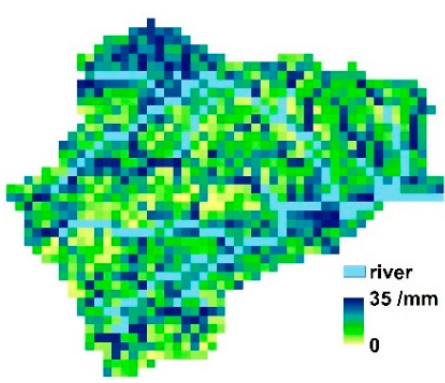

(b)

Figure 3. Spatial distribution of free water storage capacity, estimated from the topographic index for (a) the Chenhe Watershed and (b) the Changhua Watershed.

\subsection{GXM Simulations of the Chenhe Watershed}

The simulation statistics are summarized in Table 1. All calibration and validation simulations were measured using RRE and RPE; the average NS was 0.84 and 0.88 , respectively. These GXM simulations justified the topography-based estimates of $S_{M}$. Three flood events (2003090319, 2003091711, and 2010072116) were selected with the corresponding hydrographs shown in Figure 4. The average free water content changes are shown in Figure 5.

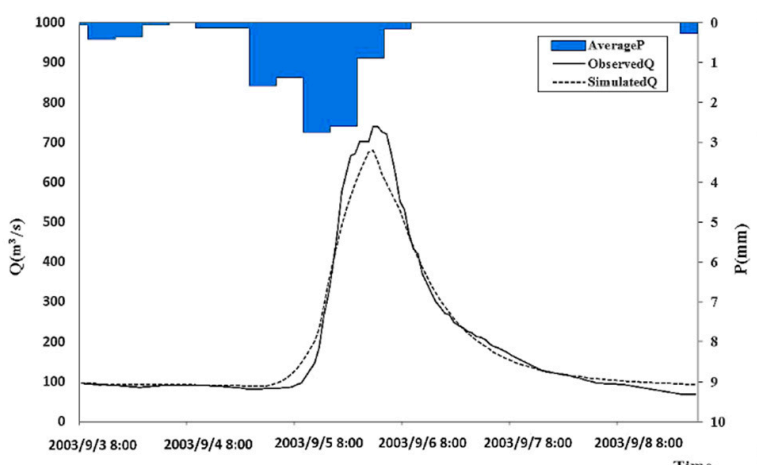

(a)

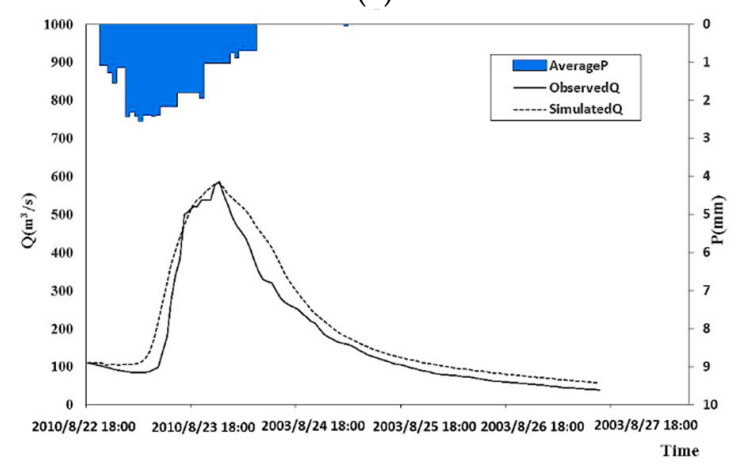

(b)

Figure 4. Cont. 


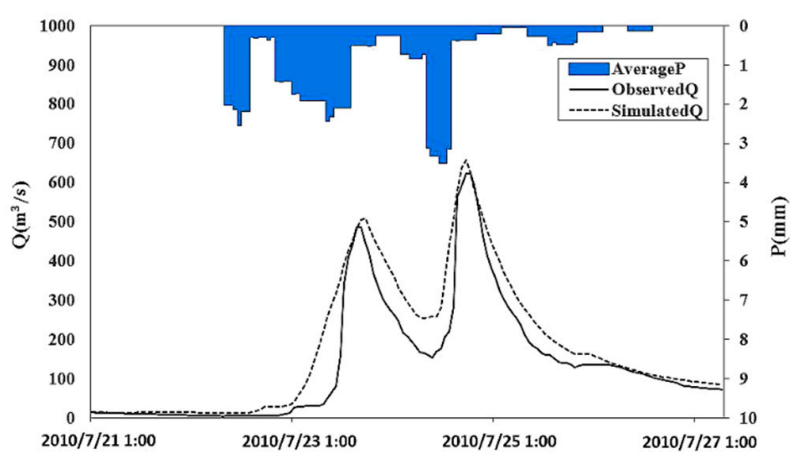

(c)

Figure 4. Simulated and observed hydrographs of the Chenhe Watershed. These examples illustrate the abilities of the Grid-Xinanjiang model (GXM) to complete hydrologic simulations. (a) 19 August-12 September 2003; (b) 2-26 September 2003; (c) 6-30 July 2010.

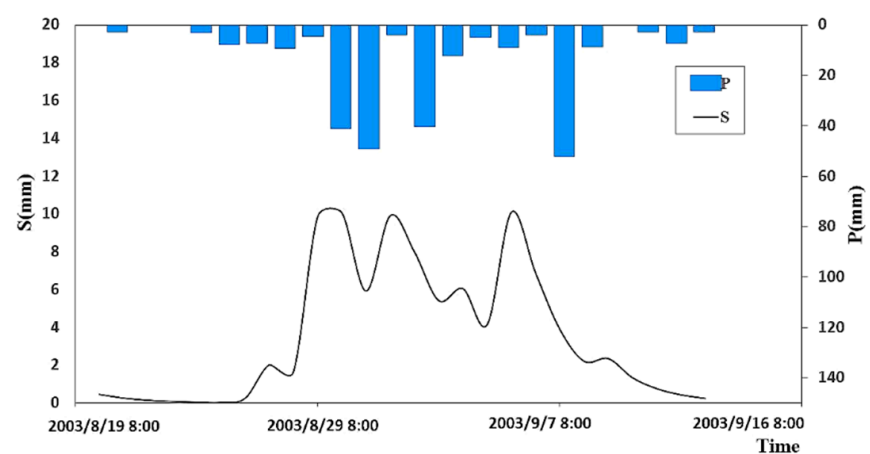

(a)

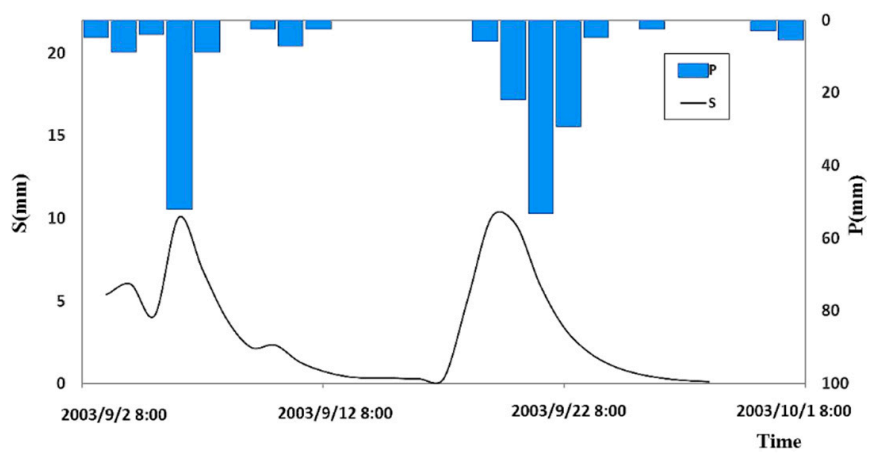

(b)

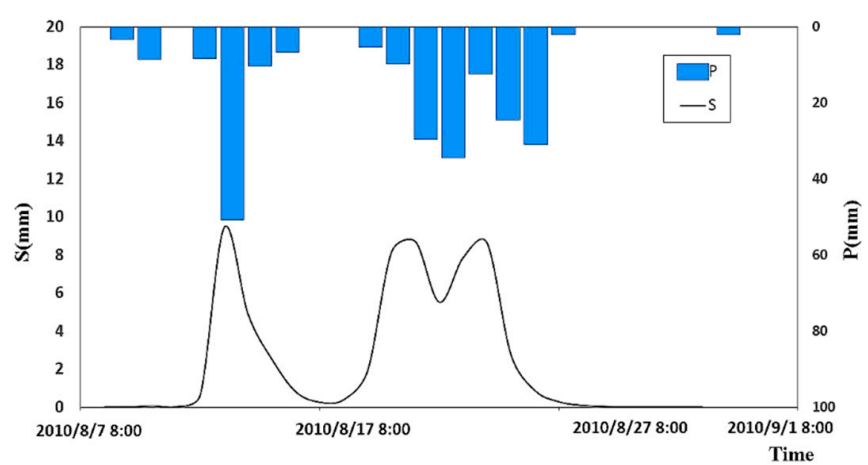

(c)

Figure 5. Hydrologic simulations showing the change process of free water storage and rainfall for the Chenhe watershed: (a) 19 August-12 September 2003; (b) 2-26 September 2003; (c) 6-30 July 2010. 


\subsection{GXM Simulations for the Changhua Watershed}

Six floods were selected over the period of 1998-2008 to calibrate the GXM parameters; four floods used for verification. Over the period of 2008-2010, four floods were selected for calibration, and three floods for validation. The results are shown in Tables 2 and 3, respectively.

Table 2. Statistics of flood simulations, before the construction of the reservoir.

\begin{tabular}{lccccccccc}
\hline Period & FloodNo & $\begin{array}{c}\mathbf{R}_{\text {obs }} \\
(\mathbf{m m})\end{array}$ & $\begin{array}{c}\mathbf{R}_{\text {sim }} \\
(\mathbf{m m})\end{array}$ & $\begin{array}{c}\mathbf{R R E} \\
\mathbf{( \% )}\end{array}$ & $\begin{array}{c}\mathbf{Q}_{\text {obs }} \\
\left(\mathbf{m}^{\mathbf{3}} / \mathbf{s}\right)\end{array}$ & $\begin{array}{c}\mathbf{Q}_{\text {sim }} \\
\left(\mathbf{m}^{\mathbf{3}} / \mathbf{s}\right)\end{array}$ & $\begin{array}{c}\text { RPE } \\
\mathbf{( \% )}\end{array}$ & RTE & NS \\
\hline \multirow{6}{*}{ Cal } & 1999062404 & 583.2 & 530.1 & -9.10 & 2100 & 1776 & -15.43 & 0 & 0.91 \\
& 1999082923 & 73.2 & 72.2 & -1.40 & 950 & 934 & -1.68 & 1 & 0.97 \\
& 2000053008 & 61.6 & 60.3 & -2.15 & 761 & 780 & 2.56 & 0 & 0.90 \\
& 2000060312 & 44.4 & 47.9 & 7.89 & 548 & 524 & -4.42 & 0 & 0.91 \\
& 2000062108 & 78.1 & 82.5 & 5.57 & 700 & 713 & 1.89 & 1 & 0.86 \\
& 2000082407 & 88.6 & 95.4 & 7.73 & 643 & 570 & -10.48 & 0 & 0.90 \\
\hline \multirow{6}{*}{ Ver } & 2001060923 & 57.0 & 63.7 & 11.71 & 715 & 718 & 0.49 & 1 & 0.94 \\
& 2002062703 & 97.4 & 96.2 & -1.22 & 1340 & 1382 & 3.13 & 1 & 0.91 \\
& 2003051207 & 72.6 & 66.7 & -8.14 & 445 & 456 & 2.45 & 1 & 0.91 \\
& 2004051205 & 87.7 & 95.2 & 8.55 & 368 & 399 & 8.37 & -2 & 0.87 \\
\hline
\end{tabular}

Table 3. Statistics of flood simulations, after the construction of the reservoir.

\begin{tabular}{|c|c|c|c|c|c|c|c|c|c|}
\hline Period & FloodNo & $\begin{array}{l}R_{\text {obs }} \\
(\mathrm{mm})\end{array}$ & $\begin{array}{l}\mathbf{R}_{\text {sim }} \\
(\mathbf{m m})\end{array}$ & $\begin{array}{c}\text { RRE } \\
(\%)\end{array}$ & $\begin{array}{c}\mathrm{Q}_{\mathrm{obs}} \\
\left(\mathrm{m}^{3} / \mathrm{s}\right)\end{array}$ & $\underset{\left(\mathrm{m}^{3} / \mathrm{s}\right)}{\mathrm{Q}_{\text {sim }}}$ & $\begin{array}{l}\text { RPE } \\
(\%)\end{array}$ & RTE & NS \\
\hline \multirow{4}{*}{ Cal } & 2008061303 & 46.7 & 53.5 & 14.64 & 507 & 514 & 1.47 & 1 & 0.90 \\
\hline & 2010022508 & 220.5 & 234.7 & 6.41 & 742 & 700 & -5.72 & 2 & 0.89 \\
\hline & 2009072316 & 83.9 & 100.7 & 19.93 & 248 & 279 & 12.56 & -1 & 0.93 \\
\hline & 2009072805 & 53.9 & 52.8 & -2.14 & 499 & 556 & 11.47 & 1 & 0.84 \\
\hline \multirow{3}{*}{ Ver } & 2009092917 & 36.3 & 32.5 & -10.53 & 580 & 531 & -8.56 & -1 & 0.87 \\
\hline & 2009073116 & 27.7 & 29.3 & 5.67 & 390 & 350 & -10.33 & 0 & 0.85 \\
\hline & 2010071305 & 121.3 & 110.1 & -9.30 & 632 & 691 & 9.29 & 2 & 0.75 \\
\hline
\end{tabular}

Before the reservoir construction, the model calibrations average NS was 0.91. The model verifications average NS was 0.90 . After the reservoir construction, the model calibrations average NS was 0.89 . For the model verifications, the average NS is 0.83 . The good performance of GXM did not demonstrate that the reservoir construction had no influence on the parameters of runoff generation. Instead, it indicated that the effect of the Huaguangtan Reservoir on the derivation of spatially varied $S_{M}$ was not obvious under the condition that the reservoir was considered a compute node for the application of GXM.

\subsection{Comparison of the XAJ Model and GXM with $S_{M}$, Estimated Using the Terrain Method}

The GXM flood simulations were compared with the traditional XAJ models in both the Changhua and Chenhe watersheds (see Figure 6). According to the statistics of flood simulations, the XAJ model simulations for the Chenhe and Changhua watersheds before the reservoir construction averaged NS 0.85 and 0.84, respectively. After the reservoir construction in the Changhua Watershed, the average NS becomes 0.81 . Both the GXM, with $S_{M}$ obtained from the terrain index, and the XAJ model, performed well. Furthermore, the GXM performed better for the Changhua Watershed's 2002062703 flood event, as well as for the Chenhe Watershed's 2003090319 flood. This enhance performance was due to the non-uniform distribution of rainfall. Figure 7a shows that rainfall during the Chenhe watershe'd 2003090319 flood was mainly concentrated in the upstream area. The water movement of the river took a longer time, causing the delay of the peak flow, when compared to the case of uniform rainfall over the watershed. Figure 6a shows that the peak flow of the XAJ model simulations occured $2 \mathrm{~h}$ before the observed; on the contrary, the GXM was in close agreement with the observation. 
Figure $6 \mathrm{~b}$ clearly shows that the GXM accurately predicted the peak flow, while the peak flow of the XAJ model simulation was $3 \mathrm{~h}$ behind.

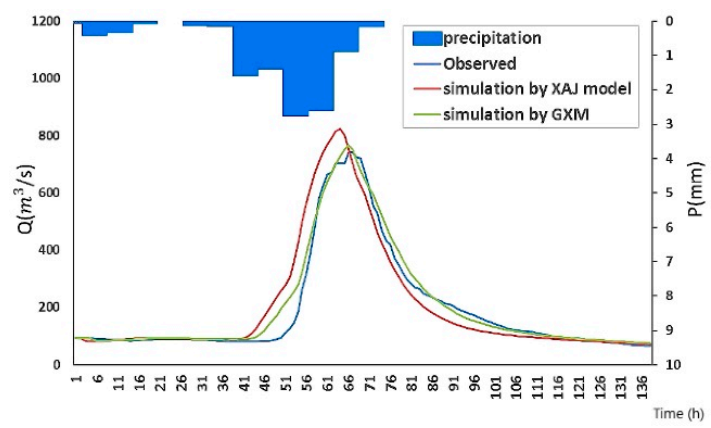

(a)

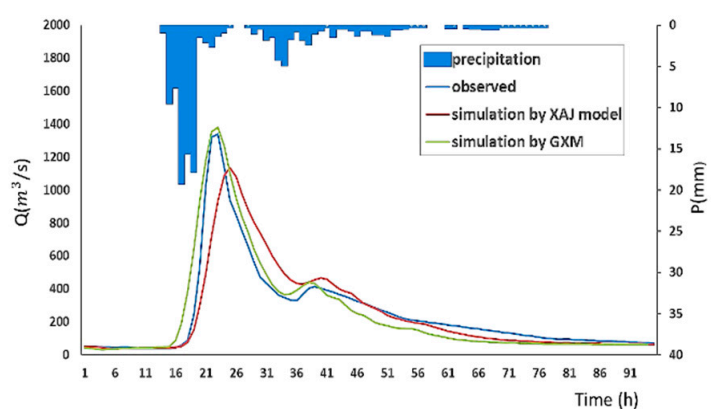

(b)

Figure 6. Examples of simulated and observed hydrographs with uniform rainfall: (a) 3-9 September 2003 (Chenhe Watershed); (b) 27 June-1 July 2002 (Changhua Watershed).

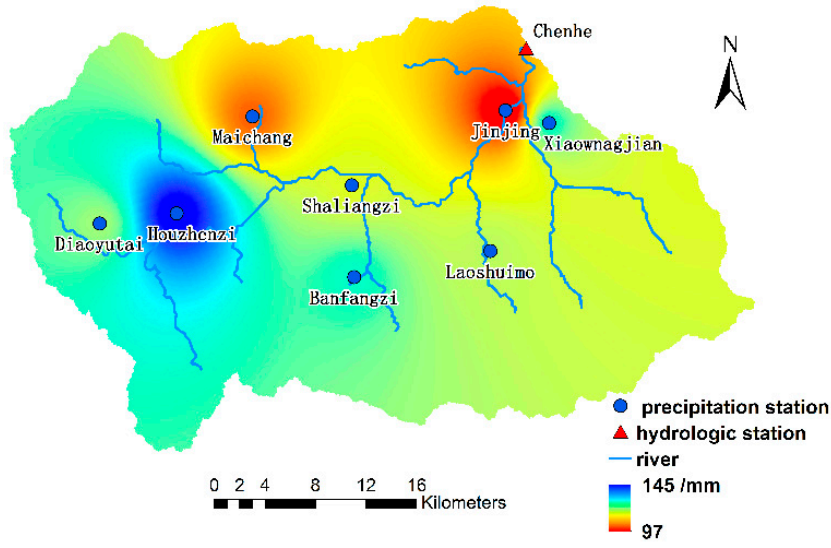

(a)

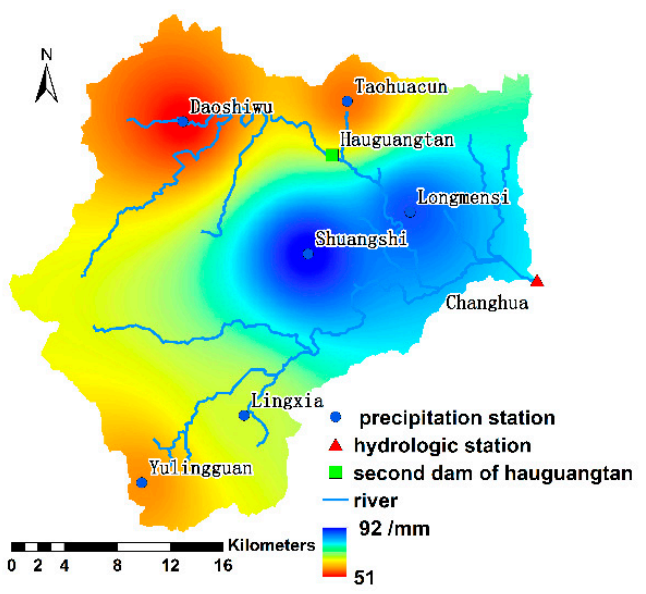

(b)

Figure 7. Rainfall distribution during the flood periods: (a) 3-9 September 2003 (Chenhe Watershed); (b) 27 June-1 July 2002 (Changhua Watershed).

\subsection{Comparison of Terrain Method and VS Method}

In order to simulate the flods in both the Changhua and Chenhe watersheds, we used the VS method to estimate $S_{M}$ and the terrain method in the GXM. The GXMs average NS-with $S_{M}$ estimated using the terrain method-was 0.88 and 0.86 for the Changhua and Chenhe watersheds, respectively. The GXMs average NS-with $S_{M}$ estimated using the VS method-was 0.82 and 0.80 for the Changhua and Chenhe watersheds, respectively. Figure 8 shows that NS was higher when $S_{M}$ was estimated using the terrain method. When $S_{M}$ was estimated using the VS method, it was correlated more with soil type than topography, as shown in Figure 9. This caused the spatial discontinuity of $S_{M}$. Therefore, the terrain method was preferred for the estimation of $S_{M}$.

The computational efficiency of GXM was of particular importance, given the model was proposed for flood simulation and real-time forecasting. According to the analysis of Yao et al. [49], the cell size of $1 \mathrm{~km}$ was more appropriate when the GXM was applied to the medium-sized watersheds (e.g., the Chenhe and Changhua watersheds). In addition, the soil and vegetation data at $1 \mathrm{~km}$ resolution were available for our study areas. Therefore, we used the DEM on a grid scale of $1 \mathrm{~km}$. However, the resolution of DEM had an important effect on calculating the topographic index [50-52]. The derivation of spatial distribution of $S_{M}$ was affected by the resolution of the DEM, specifically when using the proposed terrain method. Generally, the homogenization of spatial 
distribution of topographic index was more obvious when using the coarser DEM. In this case, the heterogeneity of the spatial distribution of $S_{M}$ derived from the terrain method was smaller. The derived distribution of $S_{M}$ for the Chenhe and Changhua watersheds may be homogenized, considering that the relatively coarse DEM was used. Furthermore, it will be necessary to investigate whether a more accurate distribution of $S_{M}$, as well as an improved performance of GXM, can be obtained through the use of DEM with a higher resolution.

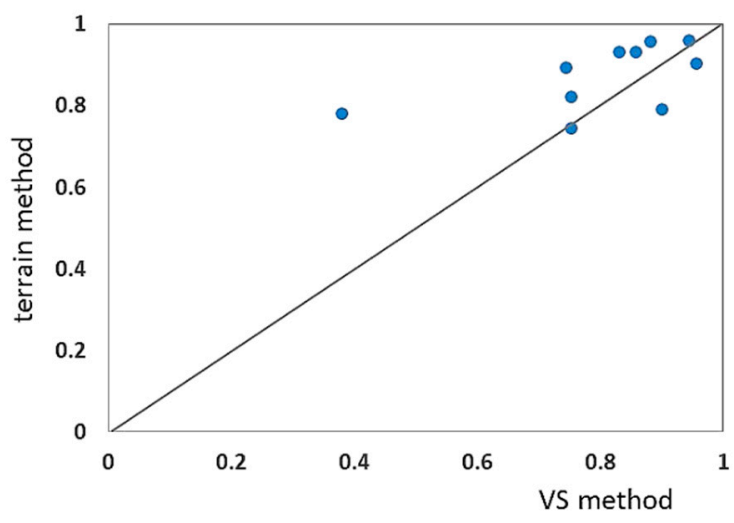

(a)

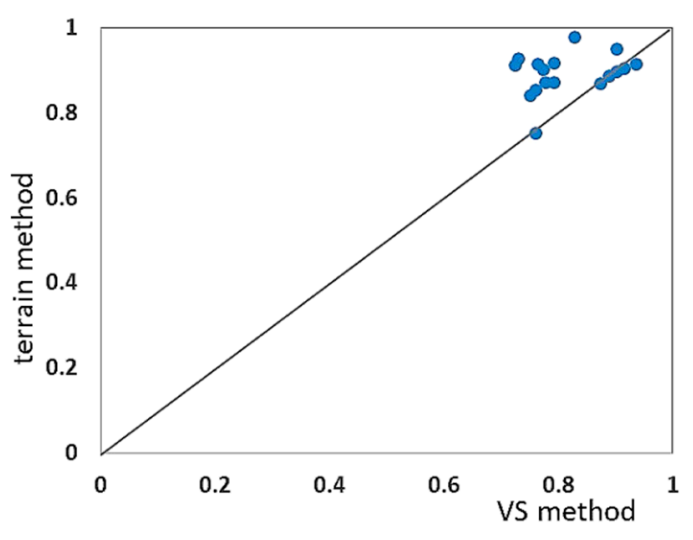

(b)

Figure 8. The comparison of NS flood simulation results, using the terrain method and the VS method. (a) the Chenhe Watershed; (b) the Changhua Watershed.

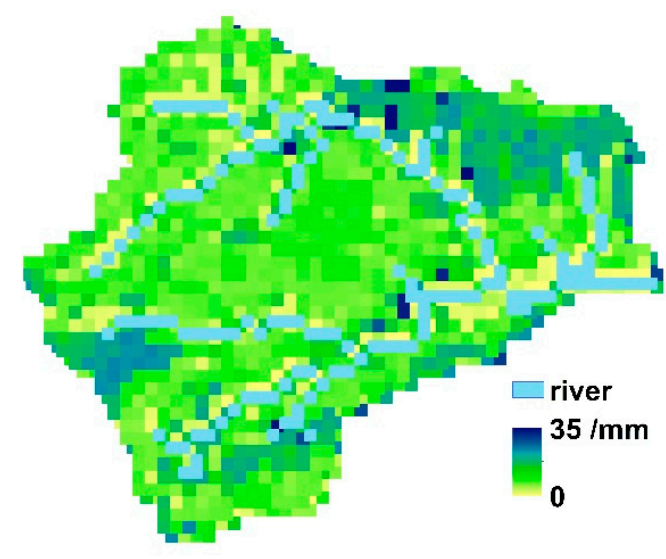

(a)

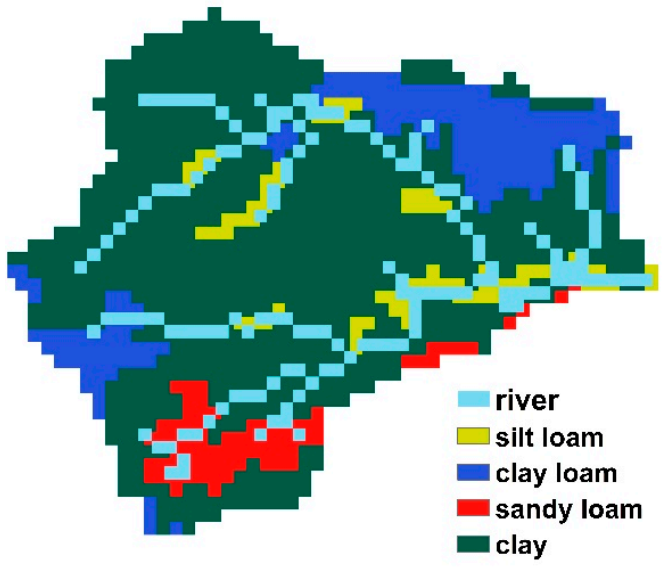

(b)

Figure 9. Spatial distribution of $S_{M}$, estimated using the VS method and soil in the Changhua Watershed: (a) $S_{M}$ estimated using the VS method (b) Spatial distribution of soil.

\section{Conclusions}

In this study, we proposed an improved method to estimate the spatial variability of free water storage capacity, based on topographic index, which was easily extracted from the DEM. The estimated spatial distribution was tested in the GXM. The results indicated that more promising simulations can be obtained from GXM simulations using an original estimation method based on vegetation and soil properties.

We compared the XAJ model and the GXM when using $S_{M}$, which was estimated by the terrain method, which simulated the impact of land surface in watersheds after inhomogeneous rainfall during the runoff process. With inhomogeneous rainfall input, the simulation in this study shows that the GXM using $S_{M}$ - estimated by the terrain method-obtained more accurate results than the XAJ model. Moreover, the comparative analysis of the free water storage capacity of the Changhua 
and Chenhe watersheds demonstrated how different topographies lead to differences in the spatial distribution characteristics of $S_{M}$. Locations with larger values of free water storage capacity generally corresponded to locations with higher topographic index values, such as in the riparian region. In addition, the terrain method overcame the deficiencies of the VS method, as it made $S_{M}$ continuously change and avoided mutation, due to vegetation or soil changes. This also ensured the continuity of the watersheds hydro-physical characteristics.

Although our preliminary tests demonstrated the potential value of our proposed method, further improvement and research may be needed to achieve a better implementation of this method. Ongoing research could focus on analyzing the effect of different DEM resolutions, such as $30 \mathrm{~m}$ and $90 \mathrm{~m}$, on the estimation of the spatial distribution of free water storage capacity, in addition to investigating whether more reasonable spatial patterns of $S_{M}$ could be obtained using a DEM with a higher resolution.

Author Contributions: B.T. carried out the writing-original draft preparation and methodology in the article. Z.L. provided the resources, funding acquisition, investigation and administration for the research. C.Y. carried out conceptualization, formal analysis and data curation in the article. J.W. carried out validation and writing-review \& editing in the article. Y.H. carried out software and investigation for this research.

Funding: This work was supported by the National Key R\&D Program of China (Grant No. 2016YFC0402705), the National Natural Science Foundation of China (51679061), the Nonprofit Industry Financial Program of MWR of China (201501022), the Fundamental Research Funds for the Central Universities (2016B04714).

Acknowledgments: We sincerely thank the anonymous reviewers and the editors for their helpful and constructive comments.

Conflicts of Interest: The authors declare no conflict of interests regarding the publication of this paper.

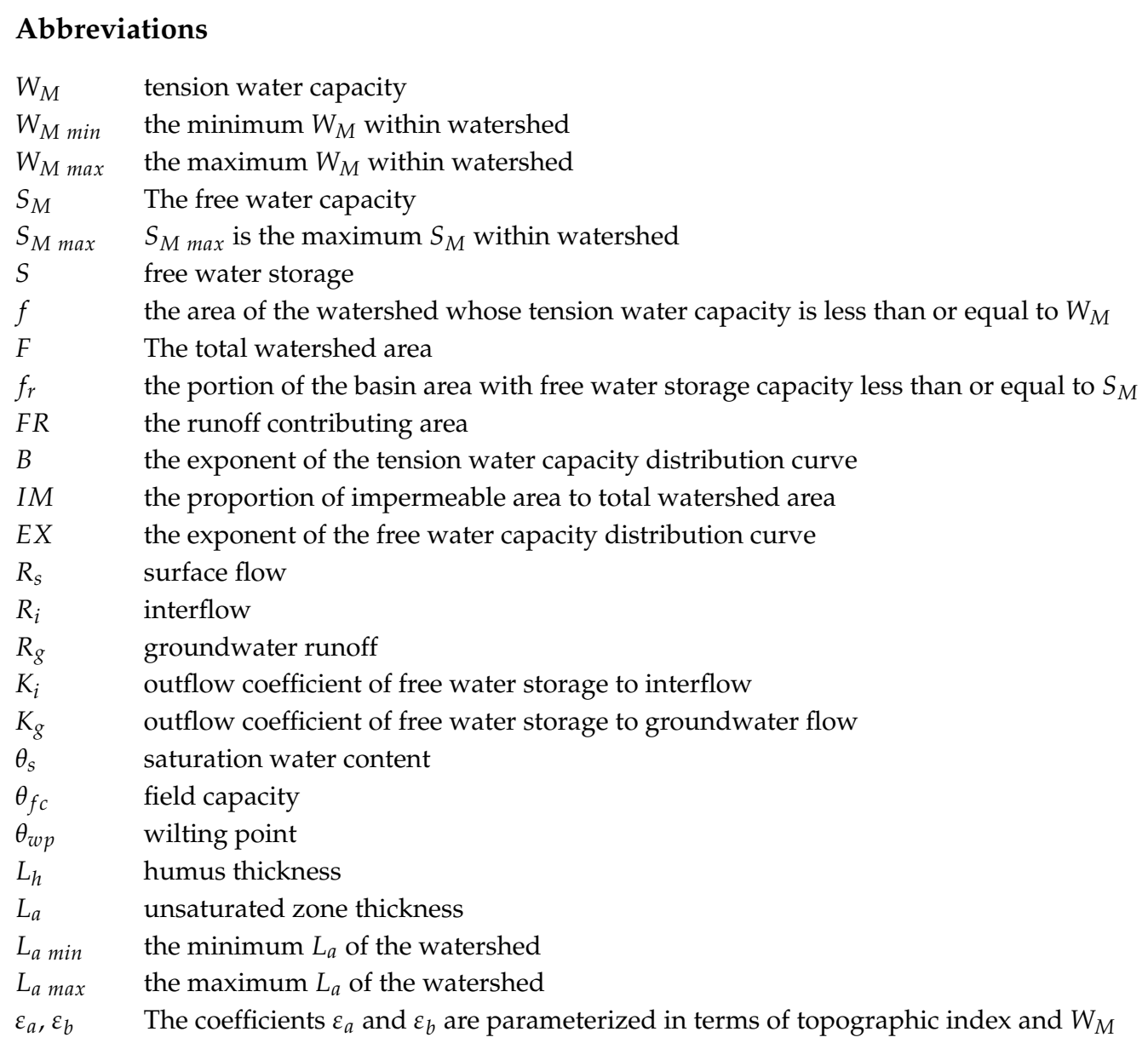


$\mathrm{Ti} \quad$ the topographic index

$\mathrm{Ti} i_{\text {min }}$ the minimum topographic index of the watershed

$T i_{\text {max }}$ the maximum topographic index of the watershed

$\alpha \quad$ empirical coefficients (refer to Shi et al., 2008)

$\beta \quad$ empirical coefficients (refer to Shi et al., 2008)

\section{References}

1. Tanakamaru, H. Parameter estimation for the Tank model using global optimization. Trans. Jpn. Soc. Irrig. Drain. Rural Eng. 1995, 63, 103-112.

2. Zhao, R.J.; Zhuang, Y.L.; Fang, L.R.; Liu, X.R.; Zhang, Q.S. The Xinanjiang Model, 2nd ed.; Singh, V.P., Ed.; Water Resources Publications: Highlands Ranch, CO, USA, 1995; pp. 371-381. ISBN 978-1-887201-74-2.

3. Perrin, C.; Michel, C.; Andréassian, V. Improvement of a parsimonious model for streamflow simulation. J. Hydrol. 2003, 279, 275-289. [CrossRef]

4. Paudel, M.; Nelson, E.J.; Downer, C.W.; Hotchkiss, R. Comparing the capability of distributed and lumped hydrologic models for analyzing the effects of land use change. J. Hydroinform. 2011, 13, 461-473. [CrossRef]

5. Meselhe, E.A.; Habib, E.; Oche, O.C.; Gautam, S. Performance evaluation of physically based distributed hydrologic models and lumped hydrologic models. In Proceedings of the World Water and Environmental Resources Congress, Salt Lake City, UT, USA, 27 June-1 July 2004; pp. 1-10.

6. Flint, A.L.; Flint, L.E.; Bodvarsson, G.S.; Kwicklis, E.M.; Fabryka-Martin, J. Evolution of the conceptual model of unsaturated zone hydrology at Yucca Mountain, Nevada. J. Hydrol. 2001, 247, 1-30. [CrossRef]

7. Clark, M.P.; Slater, A.G.; Rupp, D.E.; Woods, R.A.; Vrugt, J.A.; Gupta, H.V. Framework for understanding structural errors (fuse): A modular framework to diagnose differences between hydrological models. Water Resour. Res. 2008, 44, 421-437. [CrossRef]

8. Beven, K.; Binley, A. The future of distributed models: Model calibration and uncertainty prediction. Hydrol. Process. 2010, 6, 279-298. [CrossRef]

9. Li, Z.J.; Yao, C.; Wang, Z.H. Development and application of Grid-based Xinanjiang model. J. Hohai Univ. 2007, 35, 131-134. (In Chinese)

10. Bao, H.J.; Zhao, L.N.; He, Y.; Li, Z.J.; Wetterhall, F.; Cloke, H.L. Coupling ensemble weather predictions based on tigge database with Grid-Xinanjiang model for flood forecast. Adv. Geosci. 2011, 29, 61-67. [CrossRef]

11. Beven, K.; Freer, J. A dynamic TOPMODEL. Hydrol. Process. 2001, 15, 1993-2011. [CrossRef]

12. Silver, M.; Karnieli, A.; Ginat, H.; Meiri, E.; Fredj, E. An innovative method for determining hydrological calibration parameters for the WRF-Hydro model in arid regions. Environ. Model. Softw. 2017, 91, 47-69. [CrossRef]

13. Ambroise, B.; Freer, J.; Beven, K. Application of a generalized TOPMODEL to the small Ringelbach catchment, Vosges, France. Water Resour. Res. 1996, 32, 2147-2159. [CrossRef]

14. Quinn, P.; Beven, K.; Chevallier, P.; Planchon, O. The prediction of hillslope flow paths for distributed hydrological modelling using digital terrain models. Hydrol. Process. 2010, 5, 59-79. [CrossRef]

15. Hunter, N.M.; Bates, P.D.; Horritt, M.S.; Wilson, M.D. Simple spatially-distributed models for predicting flood inundation: A review. Geomorphology 2007, 90, 208-225. [CrossRef]

16. Ozay, M.; Esnaola, I.; Vural, F.T.Y.; Kulkarni, S.R.; Poor, H.V. Sparse attack construction and state estimation in the smart grid: Centralized and distributed models. IEEE J. Sel. Areas Commun. 2013, 31, 1306-1318. [CrossRef]

17. Blasone, R.S.; Madsen, H.; Dan, R. Uncertainty assessment of integrated distributed hydrological models using GLUE with Markov chain Monte Carlo sampling. J. Hydrol. 2008, 2008. 353, 18-32. [CrossRef]

18. Ivanov, V.Y.; Vivoni, E.R.; Bras, R.L. Catchment hydrologic response with a fully distributed triangulated irregular network model. Water Resour. Res. 2004, 40, 591-612. [CrossRef]

19. Andersen, J.; Refsgaard, J.C.; Jensen, K.H. Distributed hydrological modelling of the Senegal River Basin -Model construction and validation. J. Hydrol. 2001, 247, 200-214. [CrossRef]

20. Foglia, L.; Hill, M.C.; Mehl, S.W. Sensitivity analysis, calibration, and testing of a distributed hydrological model using error-based weighting and one objective function. Water Resour. Res. 2009, 45, 735-742. [CrossRef] 
21. Mcmichael, C.E.; Hope, A.S.; Loaiciga, H.A. Distributed hydrological modelling in California semi-arid shrublands: MIKE SHE model calibration and uncertainty estimation. J. Hydrol. 2006, 317, 307-324. [CrossRef]

22. Iorgulescu, I.; Musy, A.; Beven, K.J. Generalization of TOPMODEL for a power law transmissivity profile. Hydrol. Process. 2015, 11, 1353-1355. [CrossRef]

23. Yao, C.; Liu, K.L.; Li, Z.J. Evaluating effects of DEM resolution on distributed Grid-Xinanjiang model response. In EGU General Assembly Conference Abstracts, Proceedings of the EGU General Assembly Conference, Vienna, Austria, 22-27 April 2012; Volume 14, pp. 303-318.

24. Yao, C.; Li, Z.J.; Bao, H.J.; Yu, Z.B. Application of a developed Grid-Xinanjiang model to Chinese watersheds for flood forecasting purpose. J. Hydrol. Eng. 2009, 14, 923-934. [CrossRef]

25. Yao, C.; Li, Z.J.; Yu, Z.B.; Zhang, K. A priori parameter estimates for a distributed, grid-based Xinanjiang model using geographically based information. J. Hydrol. 2012, 468, 47-62. [CrossRef]

26. Li, Z.J.; Yao, C.; Zhang, K.; Zhu, Y.L.; Liu, Z.Y.; Li, Q.L. Research and application of the high-resolution rainfall runoff hydrological model in flood forecasting. J. Hohai Univ. 2017, 45, 472-480. (In Chinese)

27. Shi, P.; Rui, X.F.; Qu, S.M.; Chen, X. Calculating storage capacity with topographic index. Adv. Water Sci. 2008, 19, 265-267. (In Chinese)

28. Liu, J.T.; Chen, X.; Zhang, J.B.; Flury, M. Coupling the Xinanjiang model to a kinematic flow model based on digital drainage networks for flood forecasting. Hydrol. Process. 2010, 23, 1337-1348. [CrossRef]

29. Zhao, R.J. The Xinanjiang model applied in China. J. Hydrol. 1992, 135, 371-381.

30. Lin, K.R.; Lv, F.S.; Chen, L.; Singh, V.P.; Zhang, Q.; Chen, X.H. Xinanjiang model combined with curve number to simulate the effect of land use change on environmental flow. J. Hydrol. 2014, 519, 3142-3152. [CrossRef]

31. Yao, C.; Zhang, K.; Yu, Z.B.; Li, Z.J.; Li, Q.L. Improving the flood prediction capability of the Xinanjiang model in ungauged nested catchments by coupling it with the geomorphologic instantaneous unit hydrograph. J. Hydrol. 2014, 517, 1035-1048. [CrossRef]

32. Li, H.; Zhang, Y.; Chiew, F.H.S.; Xu, S. Predicting runoff in ungauged catchments by using Xinanjiang model with modis leaf area index. J. Hydrol. 2009, 370, 155-162. [CrossRef]

33. Kirkby, P.; Goodwin, A.; Thompson, G.; Selway, P. Observations of self-focusing in stripe geometry semiconductor lasers and the development of a comprehensive model of their operation. IEEE J. Quantum Electron. 1977, 13, 705-719. [CrossRef]

34. Carson, M.A.; Kirkby, M.J. Hillslope form and process. Geogr. J. 1972, 139, 140-157.

35. Jayawardena, A.W.; Zhou, M.C. A modified spatial soil moisture storage capacity distribution curve for the Xinanjiang model. J. Hydrol. 2000, 227, 93-113. [CrossRef]

36. Yang, S.T.; Dong, G.T.; Zheng, D.H.; Xiao, H.L.; Gao, Y.F.; Lang, Y. Coupling Xinanjiang model and SWAT to simulate agricultural non-point source pollution in Songtao Watershed of Hainan, China. Ecol. Model. 2011, 222, 3701-3717. [CrossRef]

37. Li, Z.J.; Yu, S.S.; Li, Q.L.; Yao, C.; Yu, Z.B.; Yan, M.C.; Rui, X.F. Regional pattern of rainfall-runoff relationship. J. Hohai Univ. 2012, 40, 597-604. (In Chinese)

38. Kravanja, G.; Knez, Ž.; Hrnčič, M.K. The effect of argon contamination on interfacial tension, diffusion coefficients and storage capacity in carbon sequestration processes. Int. J. Greenh. Gas Control 2018, 71, 142-154. [CrossRef]

39. Zhong, L.; Yao, C.; Li, Z.J.; Huang, P.N. Effect of land surface changes on design flood using Xin'anjiang-Haihe model. J. Lake Sci. 2015, 27, 975-982. (In Chinese)

40. Hale, R.L. Spatial and temporal variation in local stormwater infrastructure use and stormwater management paradigms over the 20th century. Water 2016, 8, 310. [CrossRef]

41. Immerzeel, W.W.; Droogers, P. Calibration of a distributed hydrological model based on satellite evapotranspiration. J. Hydrol. 2008, 349, 411-424. [CrossRef]

42. Infascelli, R.; Faugno, S.; Pindozzi, S.; Boccia, L.; Merot, P. Testing different topographic indexes to predict wetlands distribution. Procedia Environ. Sci. 2013, 19, 733-746. [CrossRef]

43. Qu, B.; Zhang, X.N.; Pappenberger, F.; Zhang, T.; Fang, Y.H. Multi-model grand ensemble hydrologic forecasting in the Fu River Basin using Bayesian model averaging. Water 2017, 9, 74. [CrossRef]

44. Li, H.Y.; Bao, S.S.; Wang, X.J.; Lv, H. Storm flood characteristics and identification of periodicity for flood-causing rainstorms in the second Songhua River Basin. Water 2016, 8, 529. [CrossRef] 
45. Liu, K.L.; Yao, C.; Chen, J.; Li, Z.J.; Li, Q.L.; Sun, L.Q. Comparison of three updating models for real time forecasting: A case study of flood forecasting at the middle reaches of the Huai River in East China. Stoch. Environ. Res. Risk Assess. 2017, 31, 1471-1484. [CrossRef]

46. Huang, P.N.; Li, Z.J.; Li, Q.L.; Zhang, K.; Zhang, H.C. Application and comparison of coaxial correlation diagram and hydrological model for reconstructing flood series under human disturbance. J. Mt. Sci. 2016, 13, 1245-1264. [CrossRef]

47. Zhou, M.C.; Jayawardena, A.W. Modified Xinanjiang model for runoff calculation. J. Hydraul. Eng. 2002, 33, 38-43.

48. Wan, H.; Xia, J.; Zhang, L.P.; She, D.X.; Xiao, Y.; Zou, L. Sensitivity and interaction analysis based on sobol' method and its application in a distributed flood forecasting model. Water 2015, 7, 2924-2951. [CrossRef]

49. Yao, C.; Li, Z.J.; Zhang, Y.X. Effects of DEM resolution on distributed hydrologic simulation. Adv. Sci. Technol. Water Resour. 2013, 33, 11-14. (In Chinese)

50. Wolock, D.M.; Price, C.V. Effects of Digital Elevation Map Scale and Data Resolution on a Topography-Based Watershed Model. Water Resour. Res. 1994, 30, 3041-3052. [CrossRef]

51. Molnar, D.K.; Julien, P.Y. Grid-Size Effects on Surface Runoff Modelling. J. Hydrol. Eng. 2000, 5, 8-16. [CrossRef]

52. Vázquez, R.F.; Feyen, J. Assessment of the Effects of DEM Gridding on the Predictions of Basin Runoff Using MIKE SHE and a Modelling Resolution of 600 m. J. Hydrol. 2007, 334, 73-87. [CrossRef]

(C) 2018 by the authors. Licensee MDPI, Basel, Switzerland. This article is an open access article distributed under the terms and conditions of the Creative Commons Attribution (CC BY) license (http://creativecommons.org/licenses/by/4.0/). 